\title{
Aspecte privind durerile musculoscheletale la pacienții pediatrici cu boli maligne
}

\author{
Mihaela-Ioana Chinceşan¹ Cristina Oana Mărginean' ${ }^{1}$ Maria Despina Baghiu², \\ Adienne Horvath ${ }^{3}$, Alina Grama ${ }^{1}$, Andreea Durlan² \\ ${ }^{1}$ Disciplina de Pediatrie I, Universitatea de Medicină şi Farmacie, Târgu Mureş, România \\ ${ }^{2}$ Clinica de Pediatrie I, Spitalul Clinic Judeţean de Urgenţă, Târgu Mureş, România \\ ${ }^{3}$ Disciplina de Pediatrie II, Universitatea de Medicină şi Farmacie, Târgu Mureş, România
}

\begin{abstract}
REZUMAT
Introducere. Durerile musculoscheletale sunt printre cele mai obişnuite acuze ale copilului, cele mai multe episoade fiind autolimitate. Cu toate acestea, în unele cazuri reprezintă primul semn al unei boli maligne.

Obiective. Evaluarea frecvenței şi caracteristicile acuzelor musculoscheletale ca simptome inițiale prezente la copiii nou-diagnosticați cu cancer.

Material şi metodă. Studiu retrospectiv care a inclus 231 de copii cu diferite boli maligne diagnosticați şi tratați în Clinica de Pediatrie I, Târgu Mureş, în perioada 2000-2015. Datele colectate au fost: vârsta la diagnostic, caracteristicile clinice prezentate, constatările de laborator, precum şi diagnosticele finale.

Rezultate. $23 \%$ dintre copiii cu cancer au avut simptome musculoscheletale la prima prezentare. Timpul mediu dintre debutul bolii şi diagnosticul final a fost de 60 de zile. Acuzele cele mai frecvente au fost artralgia (50\%) implicând articulațiile mari. Artrita reumatoidă juvenilă a fost cel mai frecvent diagnostic inițial, la 7 din cei 54 de pacienți (13\%). Anemia a fost cea mai frecventă modificare hematologică inițială. Toți pacienții au avut valori crescute ale VSH-ului şi LDH-ului. Malignitățile diagnosticate au fost: leucemie acută limfoblastică sau mieloblastică, limfoame şi tumori solide.

Concluzii. Diagnosticul precoce al cancerului şi tratamentul adecvat sunt esențiale pentru imbunătățirea prognosticului şi se poate realiza incluzând boala malignă în diagnosticul diferențial al afecțiunilor reumatice la copiii care acuză inițial dureri musculoscheletale.
\end{abstract}

Cuvinte cheie: dureri musculoscheletale, copii, malignitate

\begin{abstract}
Abrevieri:
AINS - antiinflamatoare nesteroidiene

CT - computer tomograf

LAL - leucemie acută limfoblastică

LAM - leucemie acută mieloblastică
\end{abstract}

\author{
LDH - lactic dehidrogenaza \\ $\mathrm{PCR}$ - proteina $\mathrm{C}$ reactivă \\ RMN - rezonanță magnetică nucleară \\ VSH - viteza de sedimentare a eritrocitelor
}

\section{INTRODUCERE}

Durerile articulare tranzitorii de la nivelul membrelor sunt comune în rândul copiilor, iar în majoritatea cazurilor se rezolvă fără nici un tratament. Aceste dureri sunt în mare parte etichetate ca fiind „dureri de creştere" benigne sau apar din cauza unor articulații hipermobile (1). Rareori aceste acuze dureroase se dovedesc a fi de origine organică şi ocazional se asociază cu o malignitate ca manifestare inițială a bolii. Leucemia acută limfoblastică este cea mai frecventă boală malignă a copilăriei, care cuprinde $25-30 \%$ din totalul tumorilor maligne pediatrice şi este cel mai frecvent neoplasm asociat cu dureri musculoscheletale la debutul bolii (2).

Manifestările musculoscheletice care se asociază cu neoplazii includ dureri osoase difuze, artrită, artralgii şi mialgii. Caracteristicile durerii sunt utile pentru orientarea medicului în precizarea diagnosticului corect. În bolile limfoproliferative, durerile osoase sunt iniţial descrise ca intermitente şi treptat devin continue, intense şi, mai ales, nocturne. În schimb, durerea din cadrul unei boli reumatice are intensitate scăzută sau moderată, apare în principal dimineața şi este acompaniată de o rigiditate caracteristică. Durerile musculoscheletale asociate cu 
neoplazii se datorează infiltrării articulare sau musculare, hemoragiei intra sau periarticulare, sau ca efect paraneoplazic mediat de factori umorali (3). Când aceste simptome predomină la debutul bolii, diagnosticul diferențial include artrita reumatoidă juvenilă, febra reumatică, lupusul eritematos sistemic şi artrita septică sau reactivă (4).

Obiectivele acestui studiu au fost de a evalua retrospectiv frecvenţa şi tipul neoplaziilor la copiii care au prezentat iniţial acuze musculoscheletale, precum şi determinarea caracteristicilor clinice şi a modificărilor de laborator, care pot sugera astfel de boli maligne.

\section{MATERIAL ŞI METODĂ}

Am efectuat un studiu de tip retrospectiv în care am inclus 231 de copii cu diferite boli maligne care au fost diagnosticați şi tratați în Clinica de Pediatrie I, Târgu Mureş, Compartimentul de Hemato-oncologie, în perioada 2000-2015. Datele colectate au fost: vârsta la diagnostic, intervalul de timp între debutul manifestărilor şi diagnosticul neoplaziei, semnele şi simptomele inițiale; testele de laborator (hemoleucograma, VSH, PCR, LDH, cupremia, feritina) şi investigațiile imagistice efectuate la internare, tratamentul inițial urmat şi diagnosticul final (de tipul neoplaziilor). De asemenea, s-a notat tipul durerii musculoscheletale: artromialgie, artralgie, artrită, dureri osoase, precum şi caracterul durerii (durere matinală, durere nocturnă, durere continuă).

\section{REZULTATE}

Din cei 231 de pacienți diagnosticați şi trataţi cu diferite boli maligne, în perioada 2000-2015, 54 de pacienți $(23 \%)$ au prezentat la debutul bolii simptome musculoscheletale. Repartiția pe sexe a celor 54 de pacienți a indicat o predominență uşoară a sexului masculin (33 de pacienţi), față de sexul feminin (21 de pacienți). Vârsta pacienților a fost cuprinsă între 3 şi 18 ani, cu o medie de vârstă de 8,4 ani.

Simptomele asociate neoplaziilor au fost prezente la debutul bolii la un număr mare de pacienți; astfel, cei 54 de pacienți cu dureri musculoscheletale au prezentat asociat la debutul bolii paloare muco-tegumentară (44 de pacienți), febră (33), oboseală (27), transpirații nocturne (5), vărsături (6), iritabilitate (21), limfadenopatie (27), dureri abdominale (12), scădere ponderală (19), alte simptome (35).

Manifestările musculoscheletale au fost de tip artromialgii la 8 pacienți, artralgii la 32 de pacienți, iar 45 de pacienți au prezentat dureri osoase. Urmărind localizările acestor dureri de tip artralgic, din cei 54 de pacienți, 24\% au asociat artralgii la nivelul umărului, 17\% lombalgii, 10\% artralgii la nivelul şoldului, $12 \%$ la nivelul genunchiului, gleznă $9 \%$, cot $5 \%$, iar $2,5 \%$ la nivelul articulației temporo-mandibulare, existând şi afectări multiple în cadrul aceluiaşi caz. Urmărind perioada din zi în care durerea apare cu o frecvență mai mare, s-a constatat că durerea musculoscheletală are un caracter predominant nocturn, mai mult de jumătate dintre pacienți, şi anume 54\%, acuzând durere nocturnă, în timp ce $31 \%$ dintre aceştia nu au avut caracterul durerii precizat, $11 \%$ au acuzat durere matinală, iar 4\% durere continuă (Tabelul 1).

TABELUL 1. Repartiția pacienților privind caracterul durerii

\begin{tabular}{|l|c|c|c|c|}
\hline $\begin{array}{l}\text { Caracterul } \\
\text { durerii }\end{array}$ & $\begin{array}{c}\text { Durere } \\
\text { nocturnă }\end{array}$ & $\begin{array}{c}\text { Durere } \\
\text { matinală }\end{array}$ & $\begin{array}{c}\text { Durere } \\
\text { continuă }\end{array}$ & $\begin{array}{c}\text { Durere nepre- } \\
\text { cizată ca mo- } \\
\text { ment al zilei }\end{array}$ \\
\hline Număr pacienți & 29 & 6 & 2 & 17 \\
\hline Procent (\%) & $54 \%$ & $11 \%$ & $4 \%$ & $31 \%$ \\
\hline
\end{tabular}

Anterior prezentării la medicul specialist oncolog pediatru, cei mai mulți pacienți au fost diagnosticați cu infecții de căi aeriene superioare sau artrită reumatoidă juvenilă; astfel, 24 de pacienți au utilizat diverse medicamente antiinflamatoare nonsteroidiene (AINS), 10 pacienți au fost trataţi cu antiinflamatoare steroidiene pentru ameliorarea durerilor, restul fiind trataţi cu alte medicamente.

Evaluarea analizelor de laborator şi a investigațiilor imagistice ale pacienților internați în compartimentul oncopediatrie este prezentată sistematizat în Figura 1.

Diagnosticul final cel mai frecvent a fost Leucemie acută limfoblastică (33 de pacienți). Celelalte diagnostice maligne au fost reprezentate de: leucemie acută mieloblastică, limfomul Hodgkin, limfom non-Hodgkin, neuroblastom, nefroblastom, sarcom Ewing, rabdomiosarcom, ameloblastom şi histiocitoză (Fig. 2).

Analizând numărul de zile de la debutul simptomelor până la diagnosticul oncologic final, reiese o medie de 60 de zile, cel mai rapid fiind diagnosticate cazurile de nefroblastom (14 zile). Diagnosticul oncologic a fost precizat pentru neuroblastom şi histiocitoză în aproximativ 50 de zile, pentru rabdomiosarcom şi limfom non-Hodgkin în 60 de zile, într-o medie de 75 de zile pentru leucemia acută, cel mai tardiv fiind diagnosticați copiii cu limfom Hodgkin şi de sarcom Ewing (100-160 de zile). 


\section{Modificări examen de laborator și imagistică}

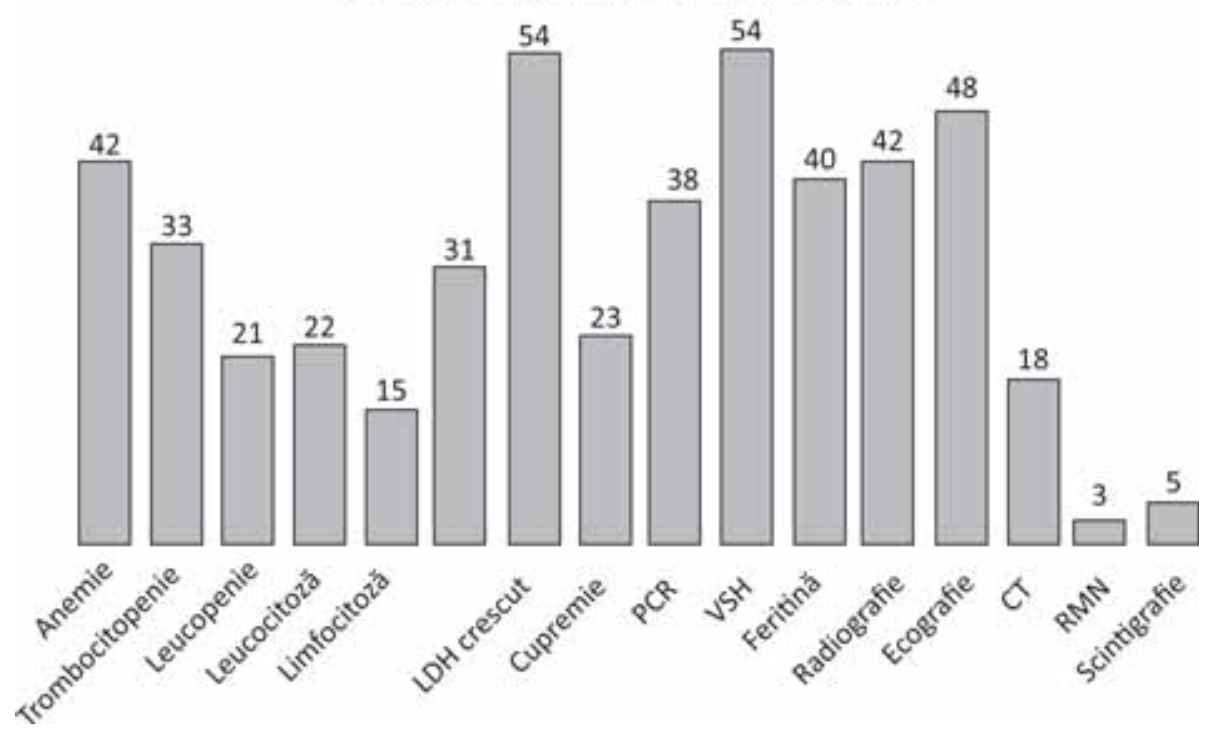

FIGURA 1. Pacienți cu dureri musculoscheletale şi modificări ale investigațiilor paraclinice

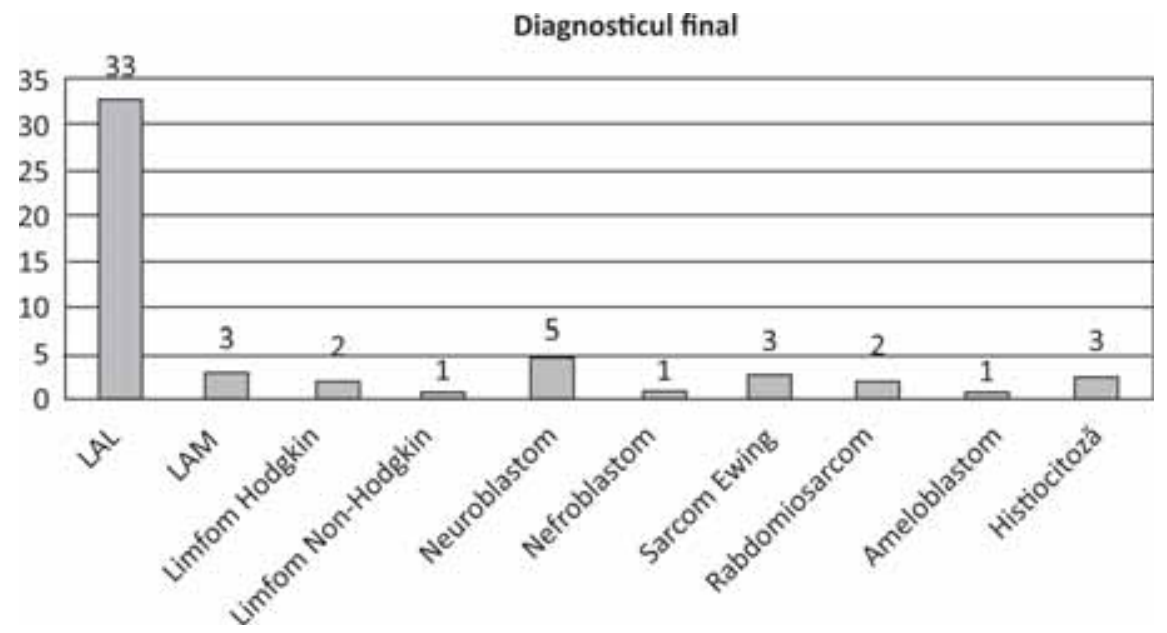

FIGURA 2. Diagnosticul oncologic al pacienților cu dureri musculoscheletale

\section{DISCUȚII}

Durerile musculoscheletale sunt frecvente la copii, mai ales la cei de vârstă şcolară şi se remit adesea fără nici un tratament. Deşi de cele mai multe ori cauza este una benignă, o etiologie malignă trebuie întotdeauna exclusă. În afecțiunile maligne, durerile musculoscheletale apar prin infiltrarea cu celule tumorale a sinovialei, periostului sau a măduvei osoase, dar şi prin depozitarea secundară de acid uric sau complexe imune; sângerarea intraarticulară secundară trombocitopeniei este un factor mai puțin frecvent (3).

În studiul nostru, simptomele musculoscheletale au fost prezente la debutul bolii la $23 \%$ dintre pacienții cu patologie oncologică, cel mai frecvent la pacienții cu leucemii. Într-un studiu efectuat pe un număr de 61 de pacienți cu leucemii, Cassia Maria Pasareli et al (5) raportează prezența acuzelor musculoscheletale la $62 \%$ dintre pacienți, îndeosebi la nivelul articulațiilor mari ale membrelor.

Anamneza este foarte importantă şi oferă detalii privind caracterul durerii. Astfel, durerea predominant nocturnă sau durerea continuă sugerează un proces malign; de asemenea, durerea osoasă metafizară sau durerea la nivelul articulațiilor mari poate reprezenta un semn de alarmă. În studiul nostru, cel mai adesea durerea a fost nocturnă şi cu atingere frecventă a articulațiilor mari (umăr, genunchi, şold) sau coloana vertebrală. Durerea intensă nocturnă care trezeşte copilul din somn nu 
este tipică pentru artrita reumatoidă juvenilă şi orientează spre o boală malignă (1). Febra, paloarea, durerea osoasă şi durerea nocturnă sunt simptome care apar frecvent în leucemie (6). Similar cu literatura, în studiul prezent aproape trei pătrimi dintre pacienții cu dureri reumatice prezentau asociat febră, paloare şi oboseală.

Am urmărit numărul de zile de la debutul simptomelor până la stabilirea diagnosticului oncologic final. Media numărului de zile a fost de 63 , cel mai precoce fiind diagnosticate cazurile de nefroblastom, în aproximativ 14 zile, iar cel mai tardiv cazurile de limfom Hodgkin (108 zile) şi sarcom Ewing (155 de zile). Unele studii similare dovedesc diagnosticarea bolii maligne la aproximativ 2 luni de la debutul acuzelor musculoscheletale (7), iar altele chiar la 5 luni (3). Întârzierea s-ar putea datora lipsei manifestărilor clinice care să sugereze neoplazia şi utilizarea terapiei cu steroizi pentru o perioadă scurtă de timp. La lotul de pacienți studiați, corticoterapia s-a administrat la 10 pacienți cu dureri musculoscheletale, iar medicația AINS la 24 de pacienți. Aceste tratamente s-au dovedit a fi temporar utile pentru ameliorarea durerii, astfel neoplazia fiind diagnosticată numai după reapariția durerii cronice. Pericolul tratamentului cu steroizi este că acesta poate masca simptomele şi testele de laborator anormale, diagnosticul corect fiind astfel întârziat. Tabloul clinic necaracteristic şi tratamentul administrat pot cauza astfel dificultăți în diagnosticul final; în studiul nostru acuzele musculoscheletale au fost etichetate iniţial ca fiind frecvent în contextul infecțiilor de căi respiratori sau în cadrul unei artrite reumatoide. Există o serie de articole în care au fost raportate cazuri de boli limfoproliferative cu simptomatologie osteoarticulară la debut, interpretate inițial ca fiind în cadrul unor boli reumatice (7-11).

În ceea ce priveşte analizele de laborator, în studiul nostru anemia a reprezentat cea mai comună modificare hematologică la pacienții oncologici, urmată de trombocitopenie. Am dori să subliniem prezența trombocitopeniei la pacienții cu leucemii şi faptul că în artrita reumatoidă juvenilă cel mai adesea pacienții prezintă trombocitoză, care rezultă din stimularea megacariocitelor de către Interleukina-6 (12). Barbosa şi colaboratorii subliniază importanța nivelului crescut de LDH (5); astfel, în grupul de neoplazii având valori de 2,2 ori mai mare decât valoarea normală, în timp ce în grupul artritelor reumatoide doar de 0,8 ori valoarea normală. În studiul nostru s-a constatat că LDH şi VSH au fost crescute la toți pacienții cu neoplazie şi dureri reumatice, rezultat ce este similar cu alte studii $(1,3,13,14)$. Markerii inflamatorii, deşi nespecifici, sunt de obicei crescuți la pacienții cu neoplazii, cum a fost observat şi în studiul prezent şi pot fi utilizaţi ca un important test de screening pentru copiii cu boli maligne care prezintă inițial dureri musculoscheletale.

Este esenţială conştientizarea posibilității existenței unei boli neoplazice la copiii care prezintă acuze musculoscheletale. Astfel, studiul nostru şi-a propus să puncteze necesitatea de a include tumorile maligne în diagnosticul diferențial al durerilor osteoarticulare inexplicabile.

\section{CONCLUZII}

Diagnosticul precoce reprezintă un factor decisiv în tratamentul şi evoluția bolilor oncologice. $\mathrm{O}$ malignitate trebuie întotdeauna exclusă la copiii cu acuze musculoscheletale. Manifestările clinice necaracteristice şi analizele de laborator nespecifice pot cauza dificultăți în diagnosticul final, astfel subliniem importanța efectuării cu rigurozitate a investigațiilor hemato-oncologice la aceşti pacienți.

Conflict of interest: none declared Financial support: none declared 